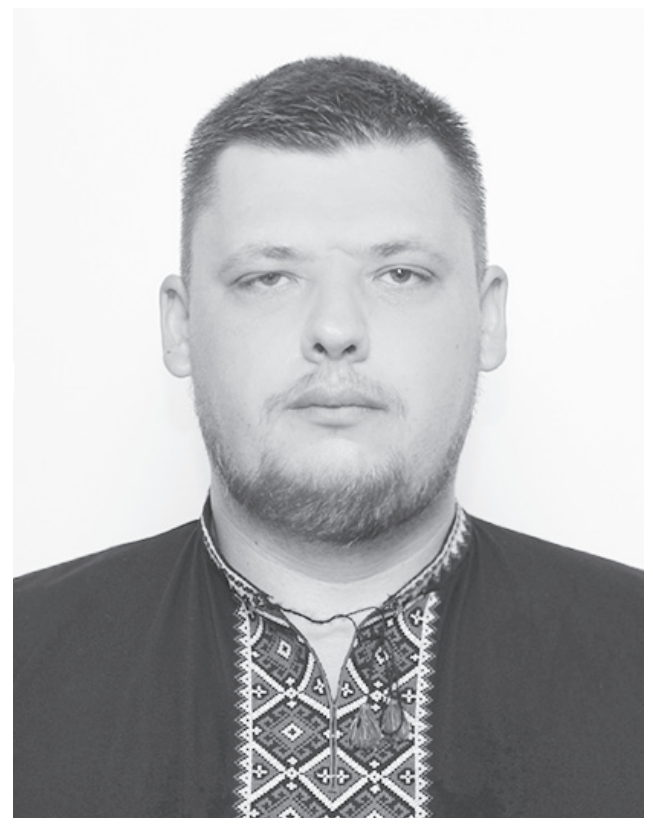
$2 о$ администрирования, Межрегиональная Академия управления персоналом, 03039, г. Киев, ул. Фрометовская, 2, тел.: (044) 49095 00, e-mail: tikhon_9563963@ukr.net

ORCID:0000-0002-7266-3829

DOI: 10.32689/2414-0562-2018-15-5-276-285

\title{
LOBISM: DEFINITION OF THE CONCEPT IN THE FIELD OF THEORETICAL-DISCUSSIVE FIELD AND NORMABLE PROCESS
}

Abstract. The article is devoted to a scientific search for the definition of lobbyism, which best describes the nature of this concept and was optimal for use in the further regulatory regulation of lobbying in Ukraine.

Starting his research from the account of the developments of foreign and domestic scientists, the author cites various approaches of researchers to the correlation of the concepts "lobbyism", "lobbying", "lobbying activity". Based on the analysis of research of predecessors, the author's corresponding definitions are offered.

The term "lobbyism" suggests to understand as the mechanism for realizing the interests of citizens and society, functioning through the interaction of these groups with the government, in all its manifestations. Lobbying is seen as an effective manifestation of lobbyism, carried out within the framework of the normative-right field, realizing in practice the desire of pressure groups to influence state authorities, to ensure the interests of citizens and society in a law-abiding 
and accountable method. The lobbying activity in this context is the professional activity of the subjects of lobbying, it is carried out in the rule-making and public-management activities, which is aimed at the adoption by the state authorities of Ukraine, local self-government bodies of Ukraine, other subjects of power, their officials and officials, deputies of all levels, Solutions that meet the interests of the customer lobbying services.

Separate attention is devoted to manifestations of lobbyism and varieties of lobbying. The manifestations of lobbyism are classified by such criteria as: scale; direction of impact; export pressure and pressure for import; operating principle; speed reaction; duration of exposure. Types of lobbying, according to the author, are: lobbying of various social structures; departmental lobbying; regional lobbying; foreign lobbying.

Keywords: lobbyism; lobbying; lobbying activity; legal regulation; bill; representation of interests.

\section{ЛОБІЗМ: ВИЗНАЧЕННЯ ПОНЯТТЯ В РАМКАХ ТЕОРЕТИКО- ДИСКУСІЙНОГО ПОЛЯ ТА НОРМОТВОРЧОГО ПРОЦЕСУ}

Анотація. Наведено визначення лобізму, яке якомога краще розкриває природу цього поняття та є оптимальним для використання в рамках подальшого нормативного врегулювання лобізму в Україні.

Враховуючи напрацювання зарубіжних та вітчизняних науковців, розглядаються різні підходи до співвідношення понять “лобізм”, “лобіювання”, “лобістська діяльність”. На основі аналізу досліджень попередників, запропоновано відповідні дефініції.

Під терміном “лобізм” пропонується розуміти механізм реалізації інтересів громадян та суспільства, який функціонує шляхом здійснення взаємодії зазначених груп з владою у всіх її проявах. Лобіювання розглядається як дієвий вияв лобізму, що здійснюється в рамках нормативно-правого поля, реалізуючи на практиці прагнення груп впливати на органи державної влади для забезпечення захисту інтересів громадян та суспільства в законослухняний і підзвітний суспільству спосіб. Лобістська діяльність у цьому контексті являє собою професійну діяльність суб'єктів лобіювання, що здійснюється в нормотворчій та державно-управлінській діяльності і спрямована на прийняття органами державної влади України, органами місцевого самоврядування України, іншими суб'єктами владних повноважень, їх посадовими та службовими особами, депутатами усіх рівнів, рішень, що відповідають інтересам замовника лобістських послуг.

Окрему увагу присвячено виявам лобізму та різновидам лобіювання. Вияви лобізму класифіковано за такими критеріями: масштаб; напрям впливу; експорт тиску та імпорт тиску; принцип дії; швидкість реакції; тривалість впливу. Різновидами лобіювання є: лобіювання різних соціальних структур; відомче лобіювання; регіональне лобіювання; іноземне лобіювання.

Ключові слова: лобізм; лобіювання; лобістська діяльність; нормативно-правове регулювання; законопроект; представництво інтересів. 


\section{ЛОББИЗМ: ОПРЕДЕЛЕНИЕ ПОНЯТИЯ В РАМКАХ ТЕОРЕТИКО- ДИСКУССИОННОГО ПОЛЯ И НОРМОТВОРЧЕСКОГО ПРОЦЕССА}

Аннотация. Представлено определение лоббизма, которое как нельзя лучше раскрывает природу этого понятия и является оптимальным для использования в рамках дальнейшего нормативного урегулирования лоббизма в Украине.

Учитывая наработки зарубежных и отечественных ученых, рассматриваются различные подходы исследователей к соотношению понятий “лоббизм”, “лоббирование”, “лоббистская деятельность”. На основе анализа исследований предшественников, предложены соответствующие авторские дефиниции.

Под термином “лоббизм” предлагается понимать механизм реализации интересов граждан и общества, функционирующий путем осуществления взаимодействия указанных групп с властью, во всех ее проявлениях. Лоббирование рассматривается как действенное проявление лоббизма, осуществляемое в рамках нормативно-правого поля, реализующее на практике стремление групп влиять на органы государственной власти для обеспечения защиты интересов граждан и общества законопослушным и подотчетным обществу образом.

Лоббистская деятельность в этом контексте представляет собой профессиональную деятельность субъектов лоббирования, осуществляется в нормотворческой и государственно-управленческой деятельности, которая направлена на принятие органами государственной власти Украины, органами местного самоуправления Украины, другими субъектами властных полномочий, их должностными и служебными лицами, депутатами всех уровней, решений, отвечающих интересам заказчика лоббистских услуг.

Отдельное внимание посвящено проявлениям лоббизма и разновидностям лоббирования. Проявления лоббизма классифицированы по таким критериям как: масштаб; направление воздействия; экспорт давления и импорт давления; принцип действия; скорость реакции; продолжительность воздействия. Разновидностями лоббирования, являются: лоббирование различных социальных структур; ведомственное лоббирование; региональное лоббирование; иностранное лоббирование.

Ключевые слова: лоббизм, лоббирование, лоббистская деятельность, нормативно-правовое регулирование, законопроект, представительство интересов.

Formulation of the problem. Lobbyism as a socio-political phenomenon and lobbying as an instrument for implementing the aspirations of the groups of pressure in practice has long been in the sight of the scholars. At the same time, some scholars use the definition of "lobbyism", other "lobbying", 
and the third - "lobbying activity". The analysis of the domestic and foreign scientific literature on the political science, public administration and law demonstrates an impressive variety of approaches to the definition of these concepts. A number of scholars identify these terms, some differentiate or even oppose them as alternatives. If domestic studies of lobbyism with rare exceptions originate from the second half of the twentieth century, then the US and Western European countries had a scientific interest in this phenomenon much earlier. The modern domestic scientific community decisively catches up with this gap. Over the past 20 years, the world has seen the study of V. F. Nesterovych, V. V. Sumska, O. V. Dyahilev, O. M. Voynych and a number of other scholars in the field of political science, public administration. Within the framework of the lawmaking process, several bills have been created to resolve domestic lobbying activities. At the same time, the diversity of approaches to lobbyism as a phenomenon, the discrepancy in the outline by scientists of the scope of the functioning of lobbyists, the lack of regulatory legislation that would fix these concepts - all this indicates the need for a systematic study, the specification of proposals to consolidate certain definitions in the relevant regulatory legal act.

Analysis of previous studies and publications. A number of domestic and foreign scientists devoted their attention to the problem of lobbyism in particular and the specific features of this phenomenon in general. The bases for this study were individual ideas, the work of A. Bentley, O. Voynych,
O. Grosfeld, O. Dyahilev, A. Yevhenyeva, M. Landeil, R. Matskevich, V. Nesterovych, A. Onuprienko, O. Porfirovych, V. Sumska, Ye. Tykhomyrova, V. Fedorenko and other researchers. Particular attention is devoted to the analysis of the relevant definitions proposed in the draft laws designed to regulate the lobbying activity in Ukraine published during the years of independence.

The purpose of the article is to define the concept of "lobbyism" and its related concepts on the basis of the analysis of scientific developments of the domestic and foreign researchers and the domestic lawmaking initiatives aimed at regulating the lobbying activity.

Presentation of the main research material. The genesis of the notion of "lobbyism" has already been considered by us in previous studies, so let us dwell in more detail on the essential features of the terms "lobbyism", "lobbying", "lobbying activity" and the content that the domestic and foreign researchers invest in them. The study of the essential content of the terminology of the lobbying activity originates from the consideration of so-called "interest groups" or "groups of pressure". In the modern political and state-management science, the basis for studying the theory of interest groups was laid by Arthur Bentley in his 1908 scientific paper "The Process of Governance". The work of Bentley marks the introduction of a conceptual notion of "group" (in contrast to class, social strata, etc., which can also be regarded as groups of people) in politics. The author analyzes the group as the basic unit of society, and the political community as a 
whole treats of a set of different "interest groups". In the sense of A. Bentley, the group is "this association of citizens that is considered not as an abstract unit of society, but as mass activity that does not associate an individual with participation in only one group, but permits its activities and many others. There is no such group that would not have its own interests, groups without interest do not exist. Society is nothing but a set of different groups of interests, and their number is limited to only one indicator - the interests for which they are created and operate" [1, p. 199]. At the same time, the scientist noted that it is the state that performs the function of maintaining balance between the groups of interests. It is interesting that such a definition of society as a whole does not contradict the domestic definition given in the Great Explanatory Dictionary of Modern Ukrainian Language: society is a collection of people united by certain relations, conditioned by a historically variable way of producing material and spiritual goods [2, p. 1417]. However, the definition of A. Bentley seems more appropriate in terms of political science and statemanagement approach.

In the future, A. Bentley's concept was actively developed by D. Truman, who referred to a more precise definition of the concept of "interest group". The American political scientist singled out the category of "political groups" that in modern political science is completely synonymous with the term "groups of pressure" - interested groups that exert pressure on state structures [3, p. 67]. Within the framework of the Truman concept, interest groups use the full range of democratic instruments to make the most profitable decision for themselves, while interacting with representatives of political parties, legislative, executive and judicial branches of power, mainly using two methods of influencing the power structures: creating favorable for self-confidence and direct conviction of the civil servants and parliamentarians. By competing with each other, they are constantly searching for access to the state institutions that are the center of making politically significant decisions in order to maximize the productive resource allocation. According to D. Truman, such a sharp competition of groups positively affects the maintenance of the stability of the political system. Such a vision of groups of pressure as a factor generating a "balance of the political system" seems too idealized for us. It is worth noting that the opponents of the "Truman concept" were criticized by the American political scientist with reason, emphasizing the relativity of the "equilibrium" of the system under conditions of the group competition. For example, R. Mills noted that the "that for one is equilibrium, for another - its just absence" [4, p. 44]. The American political scientists W. Domhoff, R. Watson and others resembled similar positions, noting that only a small minority of American citizens can influence the direction and nature of the internal and, in particular, foreign policy of the state. Rather, it's worth talking about using instruments of pressure on the state on the part of active groups rather than the all society as a whole.

With regard to the term "lobbyism", it was used in English-speaking countries since 1883 in the same sense as "lobbying", that is to denote a variety of 
corrupt acts in the adoption of normative legal acts by the public authorities [5, p. 376]. However, in the domestic scientific school, these definitions are considered as identical, and as different, and even - as mutually exclusive. For example, V. F. Nesterovych, in his study "Constitutional and Legal Aspects of Lobbying in the Legislative Process of Ukraine" defines "lobbyism" and "lobbying" at the same time and identifies them and contrasts them. In particular, the researcher notes that the use of the term "lobbyism" is "a consequence of the borrowing of Russian tradition where in the scientific works of the scientists on the given problem, since Soviet times, the lexical form of the basic concept has received the dominant role in its application". Instead, he suggests "more correct use, in particular as a legal category, of the form used in legal acts - "lobbying" which translates from English to Ukrainian into “лобіювання" [6, p. 17-18]. We can not agree with this approach, since from the point of view of public administration lobbyism is rather a mechanism for realizing the interests of citizens, whereas lobbying is a practical manifestation of lobbyism within the regulatory framework.

Repeatedly the theme of lobbyism was raised in the law-making process. So in the draft law "On the Legal Status of Groups that Are United by Common Interests (lobby groups) in the Verkhovna Rada of Ukraine" (1999), the notion "lobbyist" is absent at all, but in Art. 1 of this bill uses the category "group united by common interests (lobby group)" that refers to the association of citizens of Ukraine, representing certain economic and social in- terests of interested stratum and groups of the population, and has the right to influence the formation of Ukrainian legislation in legal ways [7]. Taking into account that this bill was one of the first in the domestic law-making process on the normalization of lobbyism, even such a determination of definitions in it can be considered a significant achievement.

The domestic constitutionalist O. Dyahilev in his study "The Legal Institute for Lobbying: Constitutional and Legal Aspects" defines the terms "lobbyism" and "lobbying" considering them in the legal and institutional sense. In particular, under lobbyism, he proposes to understand "a set of political norms that require legal legalization, are based on the indispensable constitutional right of the citizens to participate in the management of the public affairs and regulate relations at the legislative level that arise in the process of defending their citizens or their interests represented through methods not prohibited by the law of influence on the bodies of the state power and local self-government" [8, p. 26]. In this case, the researcher characterizes lobbying as "the process of influence (pressure) of the citizens or their groups (associations) to be registered in a special order on certain normative bodies of the state power and bodies of the local self-government with the purpose of promoting decision-making in the interests of the said persons, their groups (associations), or those whose interests they present". Also O. V. Dyahilev distinguishes between "lobbying activity" ("lobbyist actions") as "a more narrow, specific notion that determines the direct actions of lobbyists, the 
use of specific means of influence" [8, p. 26-27]. Noting in general the rational division of the related definitions, we still consider it appropriate to consider lobbyism not as a simple set of political norms, but as a mechanism for realizing the interests of the citizens and society that functions through the interaction of these groups with the authorities in all its manifestations.

The lobbying researcher V. Sumska also shares the notion of "lobbying" and "lobbying activity". In particular, she notes the following "to identify the concept of "lobbying" and "lobbying activity" is not feasible, since they carry a different semantic load. Lobbying should be considered as a certain social phenomenon, socio-political institution, and lobbying activity as a manifestation of lobbying embodied in the concrete actions of individuals" [9, p. 19]. In part agreeing with the researcher on the difference in the content of these concepts, however, we believe that lobbying is an effective manifestation of lobbyism which is an appropriate mechanism for realizing the interests of the citizens and society.

There is no consensus among researchers and in the context of defining the scope of lobbying. Some authors characterize lobbying as a mechanism of influence exclusively (or mainly) on the legislative activity of the parliament. Thus, the draft Law of Ukraine "On the Activities of Lobbyists in the Verkhovna Rada of Ukraine" proposed the following definition: "A lobbyist is a citizen of Ukraine registered in the Verkhovna Rada of Ukraine in the manner prescribed by the law, who, on a paid or non-paid basis, on behalf and in the interests of a legal entity (the client), within the limits and in a manner not prohibited by the legislation of Ukraine, exercises influence on the entities whose list is specified by the law in order to influence the drafting, discussion and adoption of draft laws of Ukraine and other decisions of the Verkhovna Rada and Ukraine" [10]. A slightly broader scope of lobbyism is outlined in the 2016 bill. "Lobbyism is the professional activity of the subject of lobbyism, aimed at promoting laws, other normative legal acts, their projects during the process of development, adoption, cancellation or change by their bodies of the state power of Ukraine, local self-government bodies of Ukraine, other subjects of authority of Ukraine, their civil servants and officials, deputies of all levels; the representation and protection of the customer interests in lobbying services" [11].

At the same time, a number of researchers are leaning towards a much wider scope of the lobbyists' activity. In particular, V. F. Nesterovych noted in this connection: "the restriction of the content of this concept solely to the influence on the legislative activity of the parliament does not reflect the true state of this political and legal phenomenon, since the modern institute of lobbying has de facto and de jure gone out a long time ago beyond the scope of influence only on the lawmaking of the supreme representative body of the state. In proportions of lobbying influence, other bodies of the state power, primarily the governmental institutions, as well as the local self-government bodies do not concede to the parliament" [6, p. 22-23]. We tend to agree with this position, because even in the absence of proper legal regulation, the activity of 
lobbyists manifests itself as an influence on the adoption of certain decisions by both the public authorities of Ukraine and the local self-government bodies of Ukraine, other subjects of power, their civil servants and officials, deputies of all levels. Moreover, the scale (localization) can be identified as internal (general state), and external lobbyism (the one that is implemented on the international scene). All of this requires that we define a rather wide range of activities, its structuring and standardization that should precede the formulation of the corresponding author definitions of "lobbyism", "lobbying" and "lobbying activity".

Taking into account the developments of the domestic and foreign scholars and taking into account the need to standardize the maximum number of existing manifestations of lobbying activities, we propose the following definitions:

Lobbyism is a mechanism for realizing the interests of the citizens and society that functions through the interaction of these groups with the authorities in all its manifestations. The manifestations of lobbyism can be classified according to a number of criteria, namely:

- By scale (localization): internal (general state) and external lobbyism (international arena).

- Under the direction of influence Down-up and Up-down (at the general state level); pressure exportation and pressure import (on the international scene).

- On the principle of action (direct and indirect).

- At speed of reaction: slow and fast.
- For duration of influence: operational-tactical (one-time or short-term action) and strategic (repeated, long-lasting action).

Lobbying is an effective manifestation of lobbyism within the framework of the regulatory field, realizing, in practice, the pressure of the groups of pressure to influence the state authorities to ensure the interests of the citizens and society in a law-abiding and accountable way for the society.

Depending on for whom the benefit of the issue should be solved, lobbying can be divided into varieties, namely:

- lobbying various social structures: civic organizations, movements, parties, groups, layers (trade unions, anti-war and environmental movements, business unions, etc.);

- departmental lobbying - lobbies of the state authorities (central and local), sectoral "pushing" of certain interests (so, in the Verkhovna Rada of Ukraine there are so-called "departmental deputies" who have lobbied and are lobbying in favor of, for example, energy, agro-industry or militaryindustrial complexes, etc.);

- regional lobbying - the influence on the power of the representatives of the regions that are able to "break through" the resistance and push the desired solution for the regions.

- foreign lobbying - the influence of foreign "groups of pressure" or national communities on certain state bodies in order to obtain certain decisions from them.

Lobbying activity is a professional activity of lobbying entities that is car- 
ried out in the normative and statemanagement activities, and is aimed at the adoption by the bodies of the state power of Ukraine, local self-government bodies of Ukraine, other subjects of power, their civil servants and officials, deputies of all levels, solutions that meet the interests of the customer lobbying services.

Conclusions. Lobbyism, lobbying and lobbying activity are definitions of different content, although they are, undoubtedly, interrelated. All of them urgently need to be fixed in the corresponding legal act. Lobbyism is a mechanism for realizing the interests of the citizens and society that functions through the interaction of these groups with the authorities in all its manifestations. Lobbying is an effective manifestation of lobbyism, and lobbying activity is a professional activity of the subjects of lobbying. The manifestations of lobbyism can be categorized according to scale, direction of influence, principle of action, reaction rate, etc. Lobbing is also divided into varieties, depending on who whose interests are being defended.

\section{REFERENCES}

1. Bentley A. (1967). The Process of Government. Cambridge [in English].

2. Truman D. B. (1968). The Govermental Process. New York [in English].

3. Mills C. W. (1959). Vlastvuyushchaya elita [The Power Elite]. Moscow [in Russian].

4. Busel V. T. (2005). Velykyi tlumachnyi slovnyk suchasnoi ukrainskoi movy: 250000 [Great explanatory dictionary of the modern Ukrainian language: 250000]. Kyiv; Irpin: Perun [in Ukrainian].
5. Murray J. A. H., Bradley H., Craigie W.A., Onions C. T. (Eds.).1970. The Oxford English dictionary. (Vols. VI). Oxford: Clarendon Press [in English].

6. Nesterozych, V. F. (2008). Konstytutsiino-pravovi aspekty lobiiuvannia u pravotvorchomu protsesi Ukrainy [Constitutional and Legal Aspects of Lobbying in the Law-making Process in Ukraine]. Candidate's thesis. Kyiv [in Ukrainian].

7. Proekt Zakonu Ukrainy pro pravovyi status hrup, obiednanykh spilnymy interesamy (lobistskykh) hrup u Verkhovnii Radi Ukrainy: vid 3 lystopada 1999 roku № 3188-1 [Draft Law of Ukraine on the legal status of groups united by the common interests of (lobbying) groups in the Verkhovna Rada of Ukraine: from November 3 1999, №3188-1].(n.d.). www.rada.gov.ua. Retrieved from http://w1.c1.rada.gov.ua/ pls/zweb2/webproc4_1?pf3511=7028 [in Ukrainian].

8. Diahiliev O. V. (2010). Pravovyi instytut lobiiuvannia: konstytutsiinopravovyi aspekt [Legal Institute of Lobbying: Constitutional and Legal Aspect]. Candidate's thesis. Kharkiv: Yaroslav Mudryi National Law University [in Ukrainian].

9. Sumska V. V. (2014). Instytutsionalizatsiia lobiiuvannia $\mathrm{v}$ derzhavnomu upravlinni Ukrainy [Institutionalization of lobbying in the state management of Ukraine]. Candidate's thesis. Kharkiv: National Academy for Public Administration under the President of Ukraine, Kharkiv Regional Institute of Public Administration [in Ukrainian].

10. Proekt Zakonu Ukrainy pro diialnist lobistiv u Verkhovnii Radi Ukrainy: vid 9 lystopada 2003 roku, № 8429 [Draft Law of Ukraine on the activity of lobbyists in the Verkhovna Rada of Ukraine: from November 9 2003, № 8429]. (n.d.). www.parla- 
ment.org.ua. Retrieved from http:// www.parlament.org.ua/index. php?action $=$ draft\&draft_id=1983 [in Ukrainian].

11. Proekt Zakonu Ukrainy pro lobizm: vid 21 liutoho 2017 roku, № 5144 [Draft Law of Ukraine on lobbying: from February 21 2017, № 5144]. (n.d.). rada.gov.ua. Retrieved from http://w1.c1.rada.gov.ua/pls/zweb2/ webproc4_1?pf3511=60052 [in Ukrainian].

\section{СПИСОК ВИКОРИСТАНИХ ДЖЕРЕЛ}

1. Bentley A. The Process of Government. - Cambridge, 1967. - P. 199.

2. Truman David B. The Govermental Process. - NY, 1968. - P. 67.

3. Миллс Р. Властвующая элита. - М., 1959. - С. 44

4. Великий тлумачний словник сучасної української мови : 250000 / уклад. та голов. ред. В. Т. Бусел. - К.; Ірпінь: Перун, 2005. - VIII, 1728 c.

5. The Oxford English dictionary. Being a corrected re-issue with an introduction, supplement and bibliography of a new English dictionary on historical principles / [ed. by James A. H. Murray, Henry Bradley, W. A. Craigie, C. T. Onions]. - Volume VI. - Oxford: Clarendon Press, 1970. - 820 p.

6. Нестерович B. $\Phi$. Конституційно-правові аспекти лобіювання у правотворчому процесі України : дис. ... канд. юрид. наук: 12.00.02 2008. - 212 c.

7. Про правовий статус груп, об'єднаних спільними інтересами (лобістських) груп у Верховній Раді України: Проект Закону України від 3 листопада 1999 р. № 3188-1 / / Офіційний сайт Верховної Ради України [Електронний ресурс]. - Режим доступу: http://www.rada.gov.ua

8. Дягілєв О. В. Правовий інститут лобіювання: конституційно-правовий аспект : дис. ... канд. юрид. наук: 12.00.02 / О. В. Дягілєв ; Нац. юрид. акад. України ім. Я. Мудрого. - Х., 2010. - $221 \mathrm{c}$.

9. Сумська B. B. Інституціоналізація лобіювання в державному управлінні України: дис. ... канд. наук з держ. упр.: 25.00.01, Нац. акад. держ. упр. при Президентові України, Харків. регіон. ін-т держ. упр. - Харків, 2014. - 200 c.

10. Про діяльність лобістів у Верховній Раді України: Проект Закону України від 9 листопада 2003 р. № 8429 // Сайт Лабораторії законодавчих ініціатив [Електронний ресурс]. - Режим доступу: http://www. parlament.org.ua/index.php?action= draft \&draft id=1983

11. Про лобізм: Проект Закону України від 21 лютого 2017 № 5144 // Офіційний сайт Верховної Ради України [Електронний ресурс]. - Режим доступу: http://w1.c1.rada.gov.ua/pls/ zweb2/webproc4_1?pf3511=60052 